\section{Labour plans science revamp}

\section{London}

THE British Labour Party promises a radical overhaul of the organization of science in the UK in "Pushing Back the Frontier", a policy statement on science and technology published Tuesday (11 June).

If the Labour Party is returned to power after 12 years in opposition (a general election must be called within a year), a Labour Government would appoint a Minister for Science in the Cabinet Office, responsible for the budgets of the five research councils, and co-ordinating their activities with other government departments.

The minister would be advised by a new Council on Science, Technology and Research, which will combine the present roles of the Advisory Council on Science and Technology (which now deals with general science policy issues across the whole of government) and the Advisory Board for the Research Councils (which now advises the Department of Education and Science on the research councils' budgets).

A Labour government would also restructure science in parliament, creating a new House of Commons select committee on Science, Technology and Research - the Commons committee that now oversees science also tackles education and the arts. This committee would be aided by a new Office of Technology Assessment, an independent body modelled on the US office of the same name.

Labour also proposes a package of fiscal incentives to encourage industry to invest in research and development (R\&D). Following moves in the United States, Labour would offer a 25 per cent tax credit for increases of $R \& D$ expenditure over a base year.

This credit would be over and above the current 100 per cent tax allowance for R\&D.

These moves, says Labour science and technology spokesman Jeremy Bray, would help push civil R\&D from the present 1.8 per cent of Gross Domestic Product toward a declared target of 2.5 per cent. Some defence R\&D effort will be encouraged to move into the civil sector. Bray admits that tax incentives will not be enough to reinvigorate British science, but is reluctant to attach hard figures to real-term cash injections into science.

The Department of Education (stripped of its present responsibility for the research councils' budget) would be expected to work with the Higher Education Funding Council (a union of the Universities Funding Council and the Polytechnics and Colleges Funding Council, already preempted by the current Conservative government) on new ways to support basic science. The Labour Party also plans concessions for industry-sponsored R\&D in universities.

An upturn in R\&D would prompt increased demands on training, and the document proposes to establish an Advanced Certificate of Education and Training. The certificate would be a secondary-level qualification that would replace a "jungle" of academic and vocational qualifications (including " $A$ "-levels) and encourage more students, particularly women, to take up science-based higher education, the document says.

Henry Gee

\title{
UK military favoured
}

\section{London}

Continuing concern that the benefits of British spending on defence research and development are not effectively transferred to civil industry is underlined by a report from the Parliamentary Office of Science and Technology, published last week.

The office is the British equivalent of the US Congressional Office of Technology Assessment, but has a budget only about 1 per cent as big. The defence study is the second of the more substantial reports with which the office supplements its service of informal commentaries on current issues to members of the British Parliament.

The transfer of defence technology to civil industry has been a live issue in Britain since the end of the Second World War, partly because defence research and development is a large proportion of total government spending on research - it has fallen to 44 per cent of the total only in the past few years and also a large proportion (now 20 per cent) of total spending on research by government and industry.

The parliamentary office injects a novel anxiety into the debate with the question whether the "inevitable" reduction of defence spending now in prospect will leave stranded many military research and development projects whose technology might be of value to civil industry. It is also concerned that the transformation of the defence research establishments into a government agency (from 1 April), which means that they have an incentive to reduce costs not directly related to contracts they win, may diminish their interest in technology transfer to civil industry.

While acknowledging that the present arrangement under which the Ministry of Defence is responsible exclusively for war and weapons has the virtue of avoiding muddled lines of responsibility, the office report says that the neglect of civil applications by the military risks "weakening further" the British technology base.

The most curious phenomenon brought to light is the fate of the organization called Defence Technology Enterprises, set up in 1985 with venture capital, and which appeared to be functioning well until 1990, when it "effectively ceased to operate". Tolerantly, the report notes that there were at the outset several reasons for scepticism about the enterprise, counting the gap between defence research and commercial application as the chief of these.

Wistfully, the office also noted that the British Technology Group might be well placed to take over the responsibilities of Defence Technology Enterprises were it not for the uncertainty created by the government's plans to privatise the group.

John Maddox second four-year Framework programme 